\title{
Corrosion Resistance and Microstructural Evaluation of a Plasma Nitrided Weld Joint of UNS S32750 Super Duplex Stainless Steel
}

\author{
Ferdinando Marco Rodrigues Borges ${ }^{a, b}$ (D), Wênio Fhará Alencar Borges ${ }^{c}$ * (D), \\ Rafaela Luiz Pereira Santos ${ }^{a}$ (D), Valdemar Silva Leal ${ }^{b}$,José Ribeiro dos Santos Júniora (D, \\ Anderson Oliveira Lobo ${ }^{a}$ (D), Rômulo Ribeiro Magalhães de Sousa ${ }^{a}$ (i) \\ ${ }^{a}$ Universidade Federal do Piaui (UFPI), Programa de Pós-Graduação em Ciência e Engenharia de \\ Materiais, 64049-550, Teresina, PI, Brasil. \\ bInstituto Federal de Educação, Ciência e Tecnologia do Maranhão (IFMA), Campus Monte Castelo, \\ 65030- 005, São Luís, MA, Brasil. \\ 'Instituto Federal de Educação, Ciência e Tecnologia do Maranhão (IFMA), Campus Pedreiras, \\ 65725-000, Pedreiras, MA, Brasil.
}

Received: February 15, 2021; Revised: July 09, 2021; Accepted: September 06, 2021

\begin{abstract}
Super duplex stainless steel (SDSS) combines corrosion resistance and mechanical properties, interesting to applications in the oil extraction industry. In this process, wear between the tools friction and rocky materials occurs with SDSS pipes. Due to the low tribological properties, plasma nitriding process is applied to provide a surface layer with excellent wear resistance and without significant losses in corrosion resistance. Here, conventional plasma nitriding (CPN) and cathodic cage plasma nitriding (CCPN) techniques were compared to modify SDSS surface. Before and after passing by these two nitriding processes, welded joints (WJ) were subjected to a microstructural and corrosion resistance evaluation. Aiming to characterize the final product obtained, it was used characterization techniques, such as scanning electron microscopy (SEM) and X-ray diffraction (XRD). Results show that using the $\mathrm{CPN}$ technique, at $400^{\circ} \mathrm{C}$, was responsible for providing greater resistance to corrosion, when analyzing the result of potentiodynamic polarization - jpassivation $=2.60 \times 10^{-5} \mathrm{~A}^{-\mathrm{cm}^{-2}}$ and Epite $=0.83 \mathrm{~V}$ than the CCPN technique when applied to the SSDS, and this was attributed to the formed diffusion layer, which is composed of the expanded austenite and ferrite phases.
\end{abstract}

Keywords: Super duplex stainless steels (SDSS), Plasma nitriding, Corrosion resistance.

\section{Introduction}

Super duplex stainless steel (SDSS) is a category of stainless steel that exhibit austenitic and ferritic microstructural phases in proportions of approximately 50:50 each, due to their chemical composition and heat treatment ${ }^{1,2}$. This material has a high chromium content $(24 \%-27 \%)$, and a low carbon content (less than $0.03 \mathrm{wt} . \%$ ), containing alloy elements such as molybdenum $(2.5 \%-5.0 \%)$, tungsten $(0.5 \%-2.5 \%)$, copper $(0.2 \%-2.5 \%)$ and nitrogen $(0.10 \%-0.35 \%)$. Moreover, it has several applications mainly in the petrochemical and chemical industries, in the manufacture of tubes, pumps, pressure vessels, separators and heat exchangers ${ }^{3,4}$.

Although it has these qualities, some studies present some divergences regarding the ability of SDSS to be immune to localized corrosion. For example, high corrosion resistance is a trademark of SDSS steels; however, they wear out when subjected to localized attacks, as in the case of corrosion, like pitting, crevice and tribocorrosion ${ }^{5,6}$. On the other hand, other authors claim that the high resistance to pitting is what justifies its wide use in harsh corrosion condition such as ocean engineering, oil and gas industry, etc. Still, both

*e-mail: wenio.borges@ifma.edu.br studies show that the SDSS has a complicated structure, and the corrosion resistance of this material depends heavily on the chemical composition. Pitting corrosion, for example, usually occurs when the material is in the presence of an aggressive solution, containing $\mathrm{Cl}^{-7,8}$.

Regarding the welding SDSS, the main problem is to keep the phase percentages close to proportion of fifty percent and to avoid the formation of deleterious phases (precipitates that decrease the resistance to corrosion) during the cooling process. Then, according to Lippold and Kotecki ${ }^{9}$, the heat input during welding of the SDSS steels must be limited to the range of $0.5-2.0 \mathrm{~kJ} / \mathrm{mm}$, in order to avoid the formation and precipitation of the deleterious intermetallic phases.

When heat generated in welding is so high, there is time in the cooling process of formation for deleterious precipitates, and when there are fractions of volumetric austenite with less than $25 \%$, it becomes unacceptable in most industrial applications, once the corrosion resistance is considerably reduced $^{10,11}$. This is explained by the fact that besides chromium, chemical elements, such as nickel, manganese and nitrogen give greater resistance to corrosion ${ }^{12}$. They are mainly concentrated in the austenite $(\gamma)$. While the $\gamma$ phase has 
greater resistance to corrosion when compared to ferrite $(\alpha)$. On the other hand, $\alpha$ phase has higher mechanical resistance due to the greater presence of chromium, molybdenum and silicon elements in its structure.

In order to find the closest possible percentage values to maintain the stability of mechanical strength and corrosion of SDSS steels, Hsieh et al. ${ }^{13}$ studied the effects of austenite stabilizers like nitrogen, nickel, and manganese, and the cooling times after welding on the reformation of austenite. It was found that the amount of manganese in the material does not affect the formation of austenite, and that an increase in the nitrogen and nickel contents raised the $\delta$ to transformation temperature; moreover, influencing a significant increase in austenite in the heat-affected zone (HAZ). Regarding the tribological properties of the SDSS, its behavior does not show excellent results, where its hardness is less than desirable and has low wear resistance. Paiva et al. ${ }^{14}$ applied three types of coatings with different chemical composition aiming to evaluate the tribological behavior of SDSS steel against PVD hard coatings on cemented carbide. They found that SDSS prevailing wear mechanism was adhesion for all coatings investigated, and wear rate and friction coefficient were associated to coating chemical composition.

An interesting alternative to improve the surface hardness of these materials is the use of the conventional plasma nitriding ${ }^{15-17}(\mathrm{CPN})$ and cathodic cage plasma nitriding ${ }^{18}(\mathrm{CCPN})$ techniques. CPN promotes the dissociation of nitrogen atoms, which are ionized and transported at high speeds up to the metal surface. A characteristic layer is produced by the diffusion of nitrogen on the surface of the metal, and the properties of this surface layer can be modified by varying the parameters of the process, such as temperature, treatment time and pressure.

CPN technique was applied in SDSS ASTM A182 steels with and without surface treatment to improve wear resistance without affecting corrosion resistance ${ }^{19}$, at temperatures varying from $350^{\circ} \mathrm{C}$ to $570^{\circ} \mathrm{C}$ for $2 \mathrm{~h}$. In this process, it was formed, at the surface, different nitrides that reduced the microwear resistance at temperature of $400^{\circ} \mathrm{C}$. It was observed that plasma nitriding increased surface hardness and wear resistance, but depending on the temperature used (above $450^{\circ} \mathrm{C}$ ), the corrosion resistance can be decreased. This fact occurs because at $450^{\circ} \mathrm{C}, \mathrm{Cr}$ has no mobility to pass through the modified layer. Instead, the $\mathrm{Cr}$ atoms have sufficient mobility to leave the solid substitutional solution and bond to the $\mathrm{N}$ atoms. Thus, on the surface of the stainless steel, the formation of the protective $\mathrm{Cr}$ oxide film is difficult.

Once this paper is dealing with welded joints (WJ) of super duplex steels, the behavior of the nitriding in this case differs from the nitriding that is applied to the metal as received, i.e., in the laminated form. The grain structure of the weld region is more refined, in which there are more grain contours, favoring the diffusion of the nitrogen in the crystalline lattice. This will result in higher hardness values in the weld region. In the literature, it was observed only a few papers dealing to plasma nitriding on welded joints. As an example, Alphonsa et al. ${ }^{20}$ attempted to study the welded region of an austenitic steel (AISI 304) after carrying out the plasma nitriding process. It was presented an improvement in the hardness by 3 times which could be correlated with structural changes and process parameters; however, in this study, the behavior of nitrided welds in relation to corrosion was not analyzed, with conventional nitriding being the technique used.

In this paper, we will use these two techniques: CPN and CCPN. Using this last one, there is a gain in terms of uniformity and greater hardness in the deposited layers. There are already published papers dealing with the application of both techniques in the last decade (period in which it was developed $)^{21-24}$. However, in the literature, to the best of our knowledge, there is no paper published using the CCPN technique applied to welded joints. At CCPN technique, there is a vacuum chamber, which consists of an isolated bottom plate and a cage (like a bell jar) made of titanium or stainless steel, for example. Samples are electrically insulated because they are at the top of a ceramic disk that is positioned above the bottom plate ${ }^{25}$. A voltage source applies a potential difference between the reactor wall (anode) and the cathodic cage (cathode). Atoms are plucked from the cage surface and combined with the reactive gas in the plasma atmosphere, forming compounds that attach to the samples surface ${ }^{26}$. The main advantage of CCPN is the formation of a uniform layer, regardless of the size and geometry of the sample ${ }^{27}$. For these two nitriding techniques, CPN and CCPN, the diffusion zone does not occur for the type of steel used in this work. There is only the formation of composite layers. In conventional CPN nitriding, the material that will form this layer is stripped off by sputtering from the surface of the samples, causing competition between what is stripped and what is deposited. In CCPN cathodic cage nitriding, however, the material that will form the composite layer is stripped from the walls of the cage holes, through the hollow cathode effect. In the CCPN technique, as we do not have this competition, a thicker and more uniform layer is formed.

Based on the above information, mainly in what CPN and CCPN techniques can provide to the weld in terms of tribological properties and resistance to corrosion, and the shortage of nitrided welded joints, this work has the objective of evaluating the microstructure and the corrosion resistance of welded joints with and without the nitriding process.

\section{Experimental Procedure}

\subsection{Materials and methods}

The base material used in this paper was the super duplex stainless steel UNS S3275028 with filler wire ER $2594^{1}$. The chemical compositions of the base metal and wire material are shown in Table 1 . The percentages of chromium and nickel equivalents were calculated using WRC-1992 diagrams ${ }^{29}$, according to Equations 1 and 2:

$\mathrm{Cr}_{e q}=\mathrm{Cr}+\mathrm{Mo}+0.7(\mathrm{Nb})$

$N i_{e q}=N i+35(C)+20(N)+0.25(C u)$

The MIG-MAG (Metal Inert Gas/Metal Active Gas) proceeding using surface tension transfer (STT) accomplished the welding. As filler wire, it was used the ER 2594 and protective gas $\left(\mathrm{Ar}+2 \% \mathrm{O}_{2}\right)$, and the pure Argon was used as purge gas at the root. The weld bead was made using a 
PW-455m/STT source linked to a robotic arm HP-20 for automatic displacement of the welding torch. Welding energies were controlled by automatized system that has advanced speed control, and welding was performed in two steps as parameters shown in Table 2 .

Here, standards ${ }^{11}$ were followed to avoid unbalanced phases and the appearance of intermetallic precipitates, as in both cases, they could weaken the welded joint. For the accomplishment of this work, test joints were welded to obtain a full filling of the chamfer with two passes, using the planned welding energies. After finding the welding parameters, it was transferred to the work plate. Then, it was machined to the pair, with each part having the following dimensions: $150 \times 150 \times 6 \mathrm{~mm}$, with $V_{\text {wedge }}\left(\alpha=60^{\circ}\right)$, root aperture $(d=2 \mathrm{~mm})$, and sheet thickness $(t=6 \mathrm{~mm})$.

Subsequently, the joints were arranged on a copper-joint to enable the integrity of the weld root. After welding, the specimens were drawn in a transversal direction to the weld bead, with dimensions of $20 \times 15 \times 6 \mathrm{~mm}$. All samples were milled to remove reinforcement and to plan the plate. Posteriorly, it was sanded with water sandpapers (granulometry of 200, 320, 400, 600 and $1200 \mathrm{MESH}$ ), polished on a felt disc with diamond paste $(3 \mu \mathrm{m})$, and used lubricating fluid for cleaning and finishing. Lastly, prior to each nitriding treatment, samples were cleaned in acetone for 10 minutes on an ultrasound device.

\subsection{Plasma nitriding process}

In the CPN and CCPN techniques, the same equipment was used, with a voltage source and a maximum current of $1500 \mathrm{~V}$ and $2 \mathrm{~A}$, respectively. The vacuum chamber is cylindrical with a diameter of $30 \mathrm{~cm}$ and a height of $40 \mathrm{~cm}$, made with stainless steel. The device called cathodic cage was made with AISI 304 austenitic stainless steel sheet, with thickness of $0.8 \mathrm{~mm}$, diameter of $112 \mathrm{~mm}$, height of $25 \mathrm{~mm}$ and holes with $8 \mathrm{~mm}$ diameter distributed uniformly with distance of $9.2 \mathrm{~mm}$ between centers of adjacent holes. The difference in relation to the equipment for both techniques is the presence or not of the cathodic cage and the alumina disk. Figure 1 presents an example of schematic diagram of the CCPN system.

In CCPN technique (Figure 1), the sample is placed on an alumina-insulating disk. Plasma is formed in the cage, which functions as a cathode (the chamber wall is the anode) and not directly on the sample surfaces (conventional nitriding), which remain in a floating potential. In both techniques used, firstly occur the previous treatment (called pre-sputtering), which consists of exposing the samples and cathodic cage to an atmosphere of composition balanced with $50 \% \mathrm{H}_{2}+50 \%$ Ar. Additionally, it has the function of cleaning the piece, activating the surface for interaction with the plasma and removing impurities remaining. The proportion

Table 1. Chemical composition of the super duplex stainless steel UNS S32750 and filler wire ER2594 (wt. \%).

\begin{tabular}{cccccccccccc}
\hline Material & $\mathbf{C r}$ & $\mathbf{M o}$ & $\mathbf{N i}$ & $\mathbf{C}$ & $\mathbf{N}$ & $\mathbf{M n}$ & $\mathbf{S i}$ & $\mathbf{P}$ & $\mathbf{S}$ & $\mathbf{F e}$ \\
\hline UNS S32750 & 24.9 & 3.79 & 6.88 & 0.02 & 0.26 & 0.78 & 0.25 & 0.023 & 0.001 & Bal. \\
\hline ER2594 & 26.0 & 3.09 & 10.09 & 0.02 & 0.22 & 1.08 & 0.39 & - & - & Bal. \\
\hline
\end{tabular}

Table 2. Parameters of the welding process.

\begin{tabular}{ccccc}
\hline Pass type & Average current (A) & Average voltage (V) & Wellding speed (mm/s) & $\begin{array}{c}\text { Welding energy } \\
(\mathbf{k J} / \mathbf{m m})\end{array}$ \\
\hline Root pass & 109 & 18.0 & 3.0 & 0.7 \\
\hline Filling pass & 122 & 15.3 & 1.3 & 1.4 \\
\hline
\end{tabular}

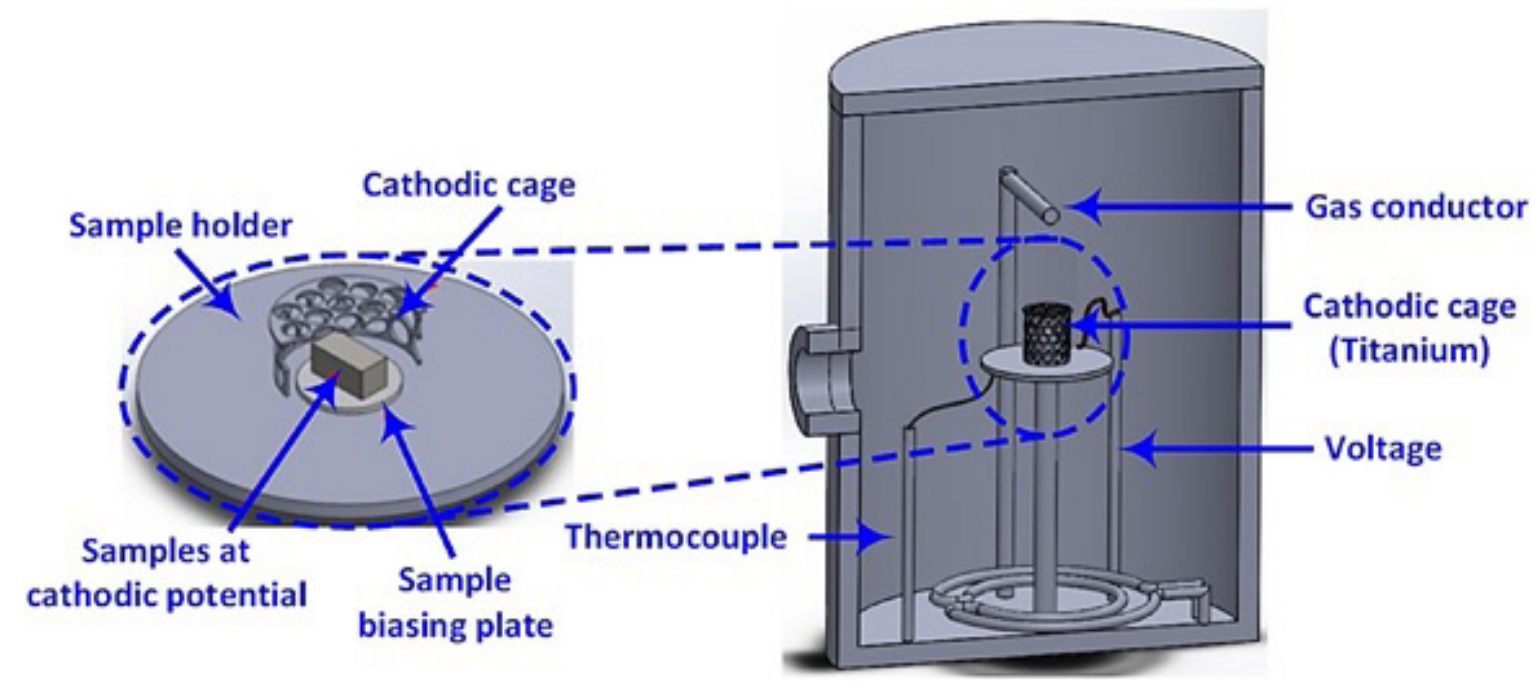

Figure 1. Schematic representation of the cathodic cage plasma deposition system, as reported by Libório et al. ${ }^{30}$. 
of gas mixtures for both CPN and CCPN is known in the literature, where more nitrogen is used when the technique used is the $\mathrm{CCPN}^{31}$, and more hydrogen is used when the technique used is the $\mathrm{CPN}^{32}$. The nitriding parameters are shown in Table 3.

To certify the phases composition present in the WJ of UNS S32750, it was used the X-ray diffraction (XRD) analysis by means of the diffractometer SHIMADZU XRD-6000 model, with theta/theta geometry and 1D pixel detector, with monochromatic radiation $\mathrm{K} \alpha(\lambda=1.540598 \AA)$ of copper target. The records were collected under the following conditions: voltage $=40 \mathrm{kV}$, current $=30 \mathrm{~mA}$, in the angular range $35-85^{\circ}(2 \theta)$ with a step of $0.02626^{\circ}$ $(2 \theta)$ and count time of $80.15 \mathrm{~s}$. The HighScore Plus version 3.0 software and ICSD database were used to identify the crystalline phases. The crystallographic charts used were 108132, 625865 and 20389. Table 4 shows the database for these crystallographic cards.

For microstructural characterization of the base metal of the nitrided layers in the welding zones, and to calculate the volumetric fractions of ferrite, it was used optical microscopy (OM). Images were captured at the top and weld profile by the Bel Photonics model MTM-1A equipment.

All the samples analyzed through OM were attacked by Behara reagent $(20 \mathrm{ml}$ of hydrochloric acid, $80 \mathrm{ml}$ of distilled water and $1 \mathrm{~g}$ of potassium metabisulphite) to reveal the microstructure. The ferrite presented a low relief when compared austenite in contact with Behara attack, once their reactivity facilitates the differentiation of these phases. Measurements of layer thickness and volumetric fractions calculations of ferrite were performed with the support of ImageJ software.

In the layer thickness measurements, ten measurements were made along the nitrided layer in which the arithmetic mean arose. During the calculation of the volumetric fraction of ferrite, a magnification of $200 x$ was adopted. Then, the image was binarized and ten fields per sample were used to obtain the percentages. Scanning electron microscopy (SEM, Quanta 250 FEG, FEI) was used to qualitatively evaluate the microstructure of the $\mathrm{WJ}$ in the upper part. The corrosion resistance analysis of material was performed by potentiodynamic polarization technique using a potentiostat (Autolab PGSTAT302N).

All electrochemical tests were carried out using a three-electrode cell, with a graphite electrode as a counter electrode, a silver/silver chloride $(\mathrm{Ag} / \mathrm{AgCl})$ electrode as reference electrode and the working electrode being the same sample of the welded plate delimited by an oring with $1 \mathrm{~cm}^{2}$ of area. Samples were kept in an open circuit for $1 \mathrm{~h}$ for system stabilization. A solution of $3.5 \% \mathrm{NaCl}$ was used as electrolyte. The polarization test was performed with initial scan potential of $0.15 \mathrm{~V}$ and a scanning speed of $1 \mathrm{mV} / \mathrm{s}$. Finally, the data was obtained using an open circuit potential, and the final potencial was $1.2 \mathrm{~V}$.

\section{Results and Discussion}

\subsection{Microstructure and weld appearance}

Figure 2a shows the microstructural analysis of the material. The presence of two different types of microstructure,

Table 3. Nitriding parameters.

\begin{tabular}{|c|c|c|c|c|c|}
\hline Material & Plasma nitriding type & Treatment time (h) & Temperature $\left({ }^{\circ} \mathrm{C}\right)$ & $\begin{array}{c}\text { Gas mixture } \\
\text { percentage }(\%)\end{array}$ & $\begin{array}{c}\begin{array}{c}\text { Work pressure } \\
\text { (mbar) }\end{array} \\
\end{array}$ \\
\hline \multirow{2}{*}{ WJ UNS S32750 } & $\begin{array}{l}\text { Conventional Plasma } \\
\text { Nitriding (CPN) } \\
\end{array}$ & \multirow{2}{*}{5} & \multirow{2}{*}{400} & $\mathrm{~N}_{2}: \mathrm{H}_{2}(20 / 80)$ & \multirow{2}{*}{2.5} \\
\hline & $\begin{array}{l}\text { Cathodic Cage Plasma } \\
\text { Nitriding (CCPN) }\end{array}$ & & & $\mathrm{N}_{2}: \mathrm{H}_{2}(80 / 20)$ & \\
\hline
\end{tabular}

Table 4. Crystallographic cards database [ICSD database $\left.{ }^{33}\right]$.

\begin{tabular}{|c|c|c|c|}
\hline Collection Code & 108132 & 64795 & 20389 \\
\hline HMS & $\mathrm{F} \mathrm{m-3} \mathrm{m}$ & $\mathrm{Im}-3 \mathrm{~m}$ & P 312 \\
\hline Structured Formula & $\mathrm{Fe} 0.94 \mathrm{C} 0.06$ & $\mathrm{Fe}$ & $\mathrm{Fe}_{3} \mathrm{~N}$ \\
\hline Structure Type & fcc(ccp)\#Cu & bcc\#W & - \\
\hline Title & $\begin{array}{l}\text { Partial molar volumes from } \\
\text { high-temperature lattice } \\
\text { parameters of iron-carbon } \\
\text { austenite }\end{array}$ & $\begin{array}{l}\text { Standard X-ray diffraction } \\
\text { powder patterns }\end{array}$ & $\begin{array}{l}\text { The electron diffraction } \\
\text { analysis of the structure of the } \\
\text { hexagonal iron nitrides }\end{array}$ \\
\hline Cell Parameter & 3.6183 .6183 .61890 .90 .90 . & 2.8862 .8862 .88690 .90 .90 & $\begin{array}{c}4.789(5) 4.7894 .41(1) 90.90 . \\
120 .\end{array}$ \\
\hline Cell Volume & $47.36\left[\AA^{3}\right]$ & $24.04\left[\AA^{3}\right]$ & $87.59\left[\AA^{3}\right]$ \\
\hline Temperature & $293[\mathrm{~K}]$ & $293[\mathrm{~K}]$ & $293[\mathrm{~K}]$ \\
\hline Chemical Name & Iron carbon $(0.94 / 0.06)$ & Iron - alpha & Iron nitride (3/1) - epsilon \\
\hline Measured Density & - & 7.87 & 7.30 \\
\hline Publication Year & 1970 & 1955 & 1954 \\
\hline Quality & -1 & -1 & -1 \\
\hline
\end{tabular}




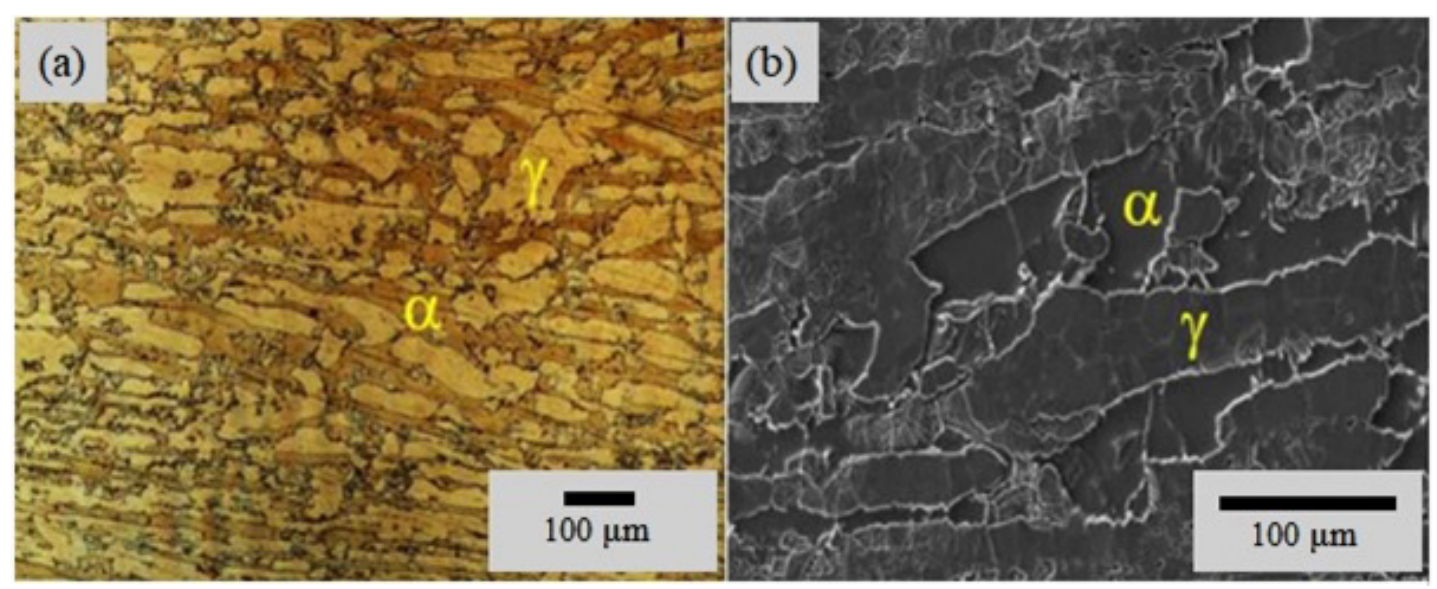

Figure 2. (a) Sample microstructure in laminated state obtained by OM, with a magnification of 200x. (b) SEM of the sample in laminated state, with a magnification of $1000 x$.

composed by ferrite lamellae ( $\alpha$-dark phase) and austenite lamellae ( $\gamma$-lighter phase) was observed. Both phases are arranged in elongated grains in the rolling direction, displaying similar characteristics to the results found by Pessoa ${ }^{34}$.

The quantification of the volumetric fractions of the ferrite was carried out on the base metal, obtaining an average value of $47.66 \%$. The values found are within the expected range, which for SDSS steels the proportion between the phases should be approximately fifty-fifty, as reported by Gunn ${ }^{35}$. Soon, the result found here is consistent with the literature. The same samples used in OM were submitted to the SEM technique to investigate in details the material microstructure. In the micrograph obtained by SEM with a magnification of $1000 x$, Figure $2 b$, it is possible to observe the presence of elongated austenitic islands $(\gamma)$ in the lamination direction, the characteristic microstructure appears in the first plane regarding the ferritic matrix, similar to the results presented in Senatore et al. ${ }^{36}$.

Figure 3 shows the XRD pattern collected from welded joint using a super duplex steel WJ UNS S32750. The diffractogram shows the presence of two distinct phases: ferrite- $\alpha$ confirmed by diffraction planes (110), (200) and (211), and austenite $(\mathrm{Fe}-\gamma)$ by diffraction planes (111), (200) and (220).

Before the welding procedure, a series of tests were performed to find the parameters that provided: (i) the filled chamfer, (ii) good penetration at the root, (iii) adequate reinforcement of the weld bead, and (iv) welding energies within of the established limits. Following the procedure established in the standards ${ }^{11}$, the super duplex steel standard was used as a starting point for welding values. In addition, it was verified that besides the chamfer fully filled, Figure 4a, and optimal penetration at the root, Figure $4 \mathrm{~b}$, the visual aspect in both cases is acceptable.

After the welding procedure, it was obtained a sample from the joint for metallography procedure. With the chemical attack, the heat-affected zone (HAZ) can be easily identified. Moreover, it was observed on the sides of the fusion zone (FZ), adjacent to the melting lines, as a region of high ferrite content and coarse granulometry (Figure 5).

The HAZ constituent phases presented in Figure 5 are in accordance with WRC-1992 diagram ${ }^{29}$. To obtain a biphasic

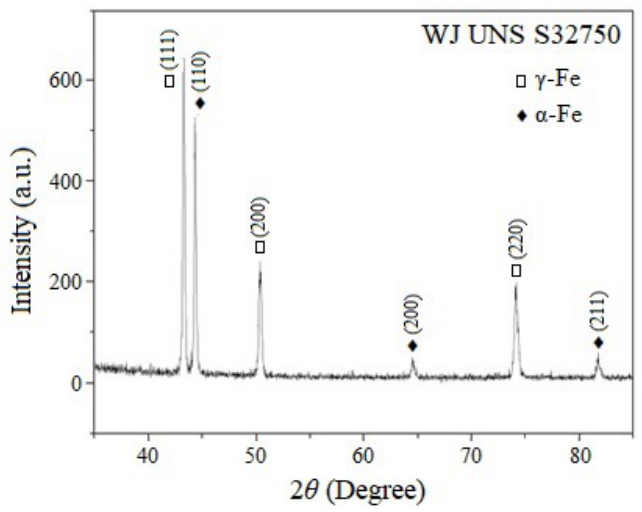

Figure 3. XRD pattern of welded joint.
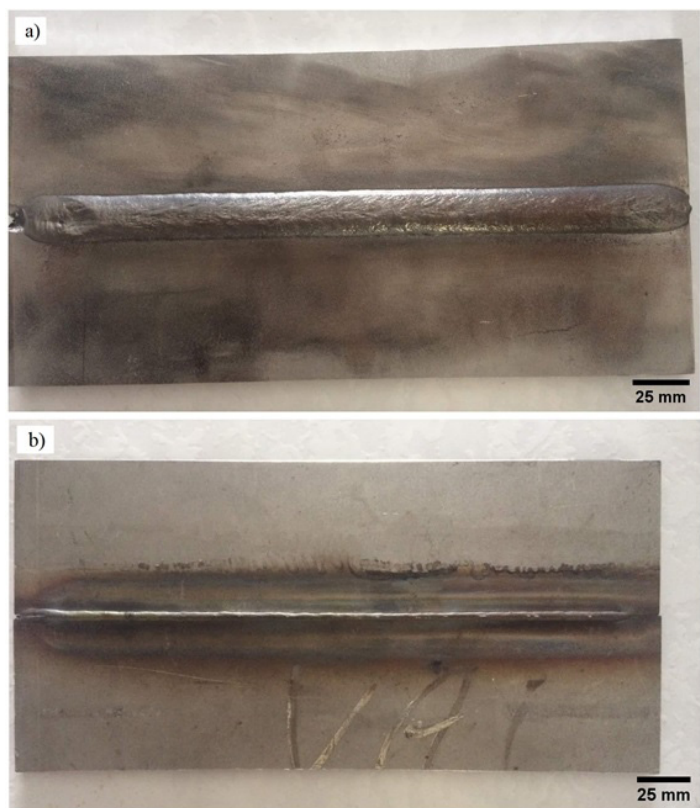

Figure 4. (a) Visual aspect of the chamfer filled. (b) Visual aspect of the weld root. 
microstructure, adjustment of the chemical composition can be made from the chromium and nickel equivalent concept. The diagram relates the chemical composition and microstructure of obtained stainless steel. Thus, the present structures were obtained by applying the chromium and nickel equivalent criteria at room temperature. Chromium equivalent is the set of elements that stabilize the ferrite phase and the nickel equivalent is the set of elements that stabilize the austenitic phase $\mathrm{e}^{9}$. From the composition of the material in the form received, the corresponding chromium and nickel equivalent were calculated using Equations 1 and 2. The amount of niobium in this material is negligible and it will not be taken into account. The values obtained were $C r_{e q}=28.69 \%$ and $N i_{e q}=12.87 \%$. Then, it was verified a duplex structure in the Schaeffler diagram using these results, and corroborating with the phases found in the XRD of Figure 3.

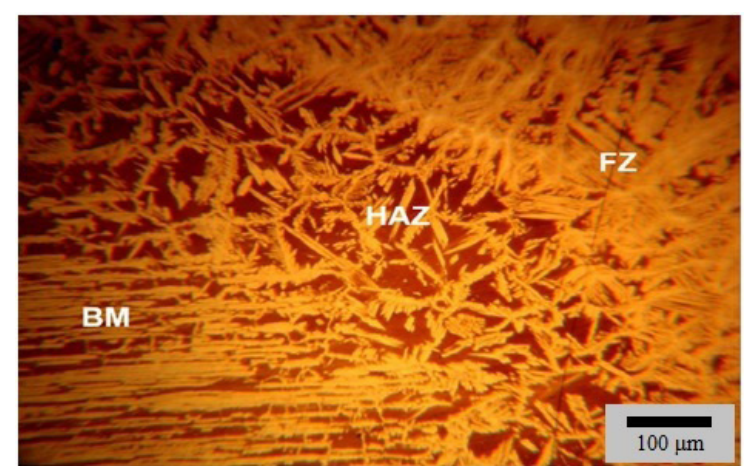

Description: BM (base metal), HAZ (heat-affected zone), FZ (fusion zone)

Figure 5. Weld joint microstructure of UNS S32750 steel obtained by OM (Magnification of 100x).
In the SDSS welding, the fusion zone temperature can reach $1500^{\circ} \mathrm{C}$. Above $1300^{\circ} \mathrm{C}$, the austenite is not stable ${ }^{37}$, which facilitates the formation of ferritic grains. The pronounced growth of the ferritic grains observed in the HAZ (Figure 5), occurs due to high temperature and cooling rate in the specified region that has been affected. High temperatures promoted the ferritic grains growth, and the rapid cooling reduced ferrite to austenite transformations. This result is similar to that reported by Videira ${ }^{38}$. In Figure 6 , it can be seen the phase transformation of the super duplex steels ${ }^{39}$. It is important to emphasize that both the base metal and the addition metal have gamagenic (austenite stabilizers) and alphagenic (ferrite stabilizers) chemical elements, as reported by Pinto $^{40}$. The consequence is that in the metal cooling, there is no complete austenization, coexisting two phases.

Three different austenite morphologies were observed for the HAZ and FZ with the welding parameters applied. Figure 7a shows the structures intragranular (inside the grain), alotriomorphic (in the grain boundary) and Widmanstätten (getting out of the grain boundary into the grain). Such morphologies were also observed in Fonseca et al. ${ }^{41}$.

The Widmanstätten austenite nucleates separately on the grain boundary surfaces of allotriomic austenite and grows within delta ferrite grain ${ }^{41}$. This behavior can be explained due the presence of larger ferritic grains and slow cooling rates, propitiating the emergence of the three austenite morphologies. When the grain boundary region is already saturated with allotriomic austenite and the cooling temperature still favors the austenitic transformation, the Widmanstätten austenite expands into the grain. Same results as observed in Ameyama et al. ${ }^{42}$ also occurred in this work as can be proven by Figure $7 \mathrm{a}$. There is benefit in

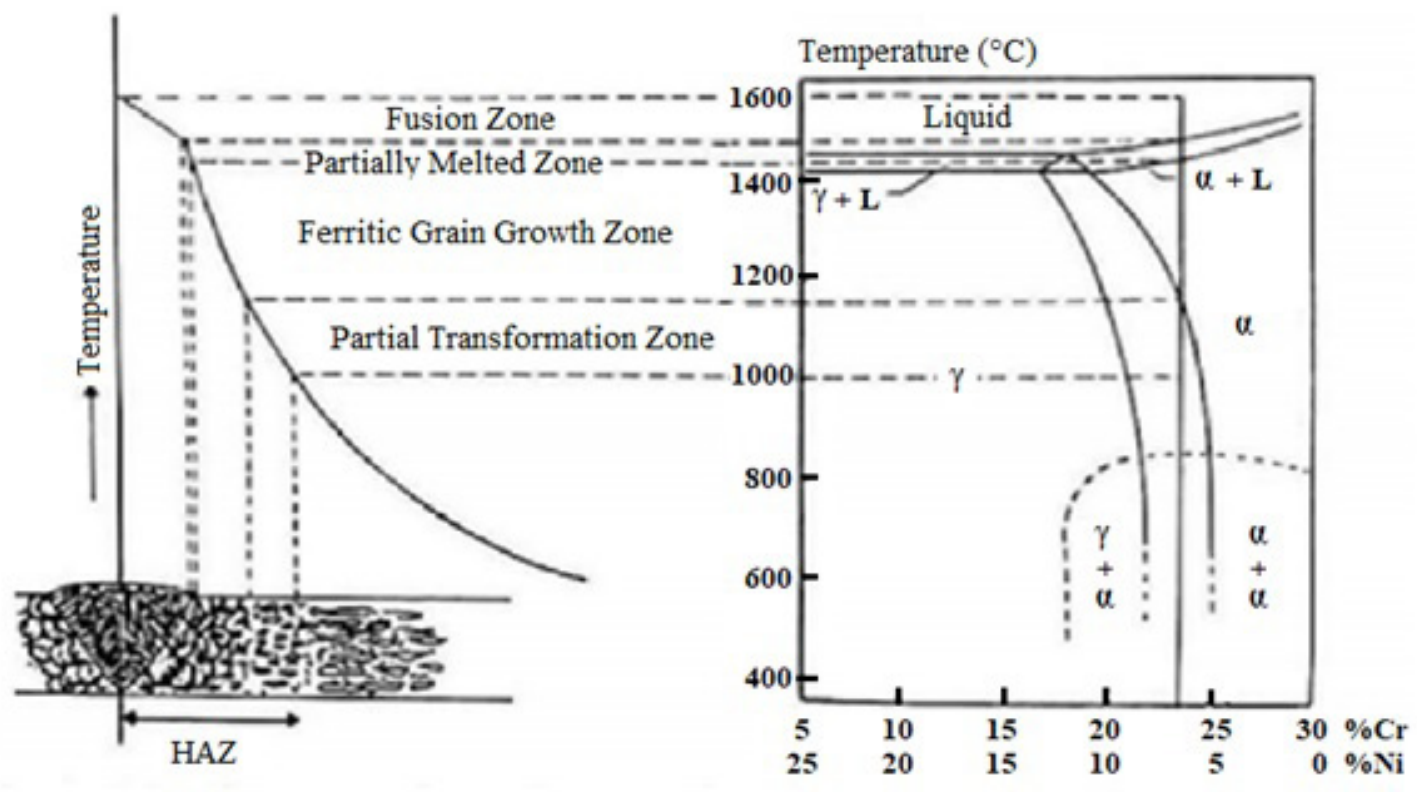

Figure 6. Microstructural changes in welded joint of $\operatorname{SDSS}^{39}$. 
the appearance of this microstructure because it promotes a greater resistance to corrosion.

Widmanstätten austenite, resulting from a martensitic reaction, may be beneficial because the presence of toughness microstructure with a low carbon content, besides being able to promote a stress relief, depending on the transformation temperature ${ }^{43,44}$. The volumetric fraction of ferrite in the HAZ was calculated based on its full extent. In the case of the FZ, top section views were used, as shown in Figure 7b.

The volumetric fraction of ferrite was calculated with the same methodology used for the base metal, from the average values. It was obtained $53.79 \%$ for $\mathrm{HAZ}$ and $35.88 \%$ for FZ. These results corroborate with the literature ${ }^{11}$ because in the MIG/MAG processes, the volumetric fractions of ferrite tend to be larger in the HAZ, while in the fusion zone these values tend to be smaller, by the use of filler wire with a higher percentage of Nickel. It is evident, then, that welding energy has different effects on the microstructural changes undergone in the HAZ when compared to those occurring in the fusion zone. This behavior can be attributed to high temperature, and consequently, lower cooling rates that occur in the FZ, which results in a longer time for diffusion processes and microstructural changes.
Figure 8a shows the diffusion layer obtained after 5 hours of conventional treatment $\left(\mathrm{CPN} 400^{\circ} \mathrm{C}\right)$ in a gas atmosphere containing $20 \% \mathrm{~N}_{2}$ and $80 \% \mathrm{H}_{2}$ at $400^{\circ} \mathrm{C}$. In the microscopy, it was possible to observe the presence of a thin and continuous layer, with a lighter shade.

In the X-ray diffractogram, Figure 9a, of the conventional plasma treatment $-\mathrm{CPN} 400^{\circ} \mathrm{C}$ - it is reasonable to infer that the nitrided layer formed on the surface was sufficiently thin and with irregularities, which allowed the detection of the substrate beyond the phases of expanded austenite $\left(\gamma_{\mathrm{N}}-\mathrm{Fe}\right)$ and expanded ferrite $(\alpha-\mathrm{Fe})$, confirming the results of OM, shown in Figure 8a. Two new peaks that were wider and shifted to slightly smaller diffraction angles appeared at $2 \theta=42.66^{\circ}$ and $2 \theta=49.52^{\circ}$, identified as expanded austenite. This indicates an increase in lattice parameters due to nitrogen supersaturation in the austenite CFC crystal cell $^{19}$. The interstitial $\mathrm{N}$ introduces large residual compression stresses associated with defects of stacking failures, which promotes hardening and can increase the hardness of 4 $\mathrm{GPa}$ to values close to $14 \mathrm{GPa}$, without a significant loss of corrosion resistance ${ }^{45}$. Furthermore, two ferritic peaks $(\alpha-F e)$ located at $2 \theta$ angles of $44.48^{\circ}$ and $64.68^{\circ}$ became
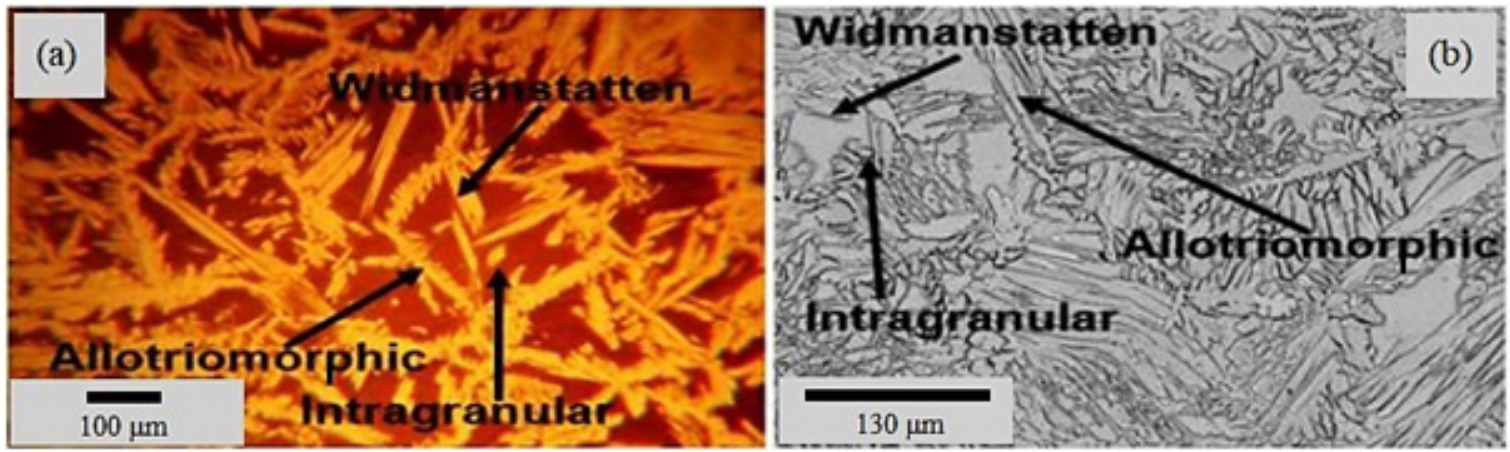

Figure 7. (a) HAZ microstructure showing three austenite morphologies from the top section view: alotriomorphic, Widmanstätten and intragranular obtained by OM (Magnification of 200x). (b) SEM of FZ exhibiting three austenite morphologies from the top section view: alotriomorphic, Widmanstätten and intragranular (Magnification of 1000x).
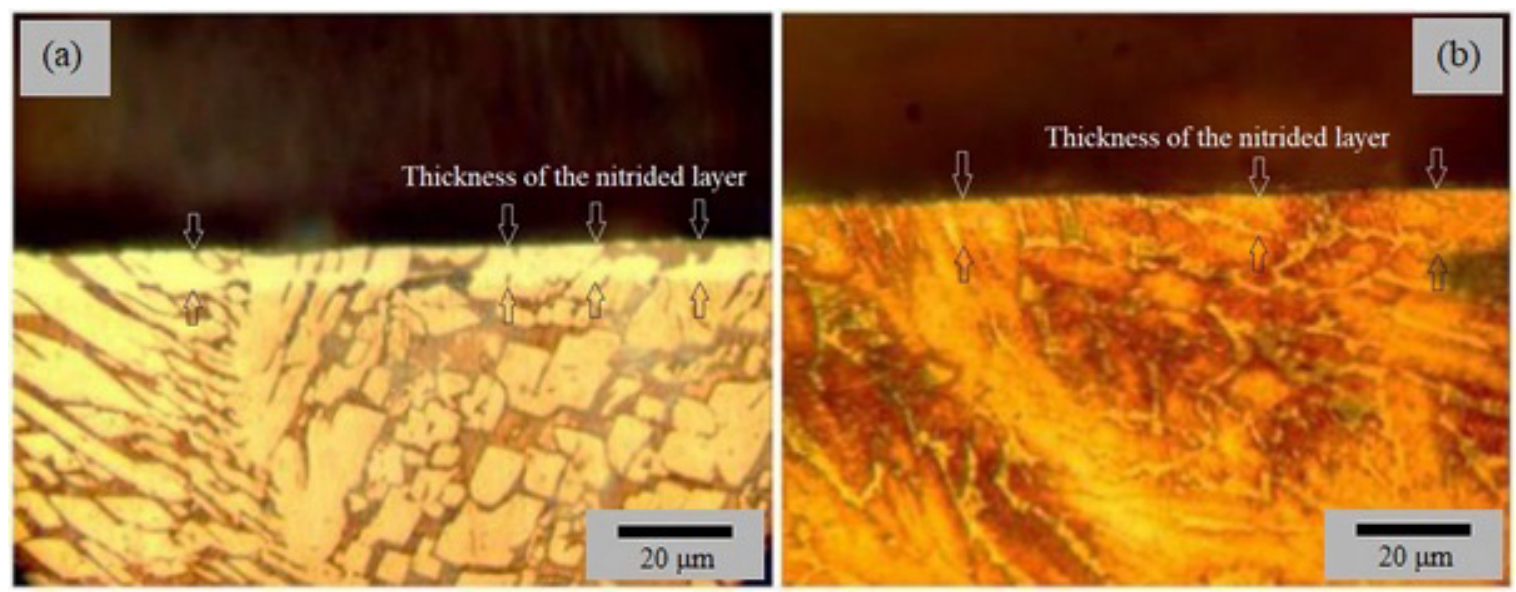

Figure 8. (a) Cross section view of the diffusion layer using $\mathrm{CPN}$ technique at $400^{\circ} \mathrm{C}$. (b) Cross section view of the diffusion layer using $\mathrm{CCPN}$ at $400^{\circ} \mathrm{C}$. 
a little wider and asymmetrical, indicating a contribution of the $\alpha_{N}-F e$, expanded ferrite phase ${ }^{16}$. The finding of the expanded austenite and expanded ferrite phases at slightly smaller angles, to the left of where the $\gamma$ and $\alpha$ phases normally diffract, is explained by the fact that nitrogen inserts into the interstices of the crystal lattice and expands the unit cell, consequently increasing the lattice parameters.

The diffusion layers obtained after 5 hours of nitriding treatment using cathodic cage plasma nitriding (CCPN at $400^{\circ} \mathrm{C}$ ) in a gas atmosphere containing $80 \% \mathrm{~N}_{2}$ and $20 \%$ $\mathrm{H}_{2}$ are shown in Figure $8 \mathrm{~b}$. Unlike conventional treatment, when CCPN was used, a compound zone was observed. When $\mathrm{CCPN}$ is used, the sputtering system is more concentered due to the presence of holes in the cage, called hollow cathode, propitiating a large ejection of iron atoms from the holes and more intense interaction with the nitrogen atoms of the atmosphere of the cage reactor, increasing the performance of the system. Therefore, the most intense formation of the $\mathrm{Fe}_{3} \mathrm{~N}$ phase can be observed ${ }^{46}$. This behavior can be seen in Figure 9a, at angles $2 \theta=40.88^{\circ}, 44.30^{\circ}$ and $46.18^{\circ}$, respectively.

Thickness measurements of the nitrided layers are shown in Table 5. It should be noted that failure to record thickness measurements for the compound zones in the conventionally treated sample does not imply that they do not exist. Irregular formation and very thin thickness of the $\mathrm{Fe}_{3} \mathrm{~N}$ phase may be occured in the CPN treatment; however, this fact may not have been verified by the used technique.

Figure $9 \mathrm{~b}$ shows the polarization curves obtained in $3.5 \% \mathrm{NaCl}$ solution for a super duplex stainless steel weld joint without the nitriding process, conventional plasma and cathodic cage techniques. The sample curves show a welldefined active, passive and transpassive dissolution regions.

The slope of the curve with respect to the axis of the current density in the passivation region of the sample without nitriding is smaller than that of the nitrided samples. This behavior is related to the presence of the chromium oxide film that naturally appears in the stainless steels in contact with the atmosphere. Taking into account that the weld region presented a high percentage of austenite, this contributed to the high corrosion resistance. Thus, it can be considered that the intentional welding energy used, corroborates these large formations of the austenite phase and, consequently, greater resistance to degradation.

Among the nitrided samples, the corrosion resistance obtained by the $\mathrm{CPN}$ at $400^{\circ} \mathrm{C}$ was higher than the $\mathrm{CCPN}$ at (a)

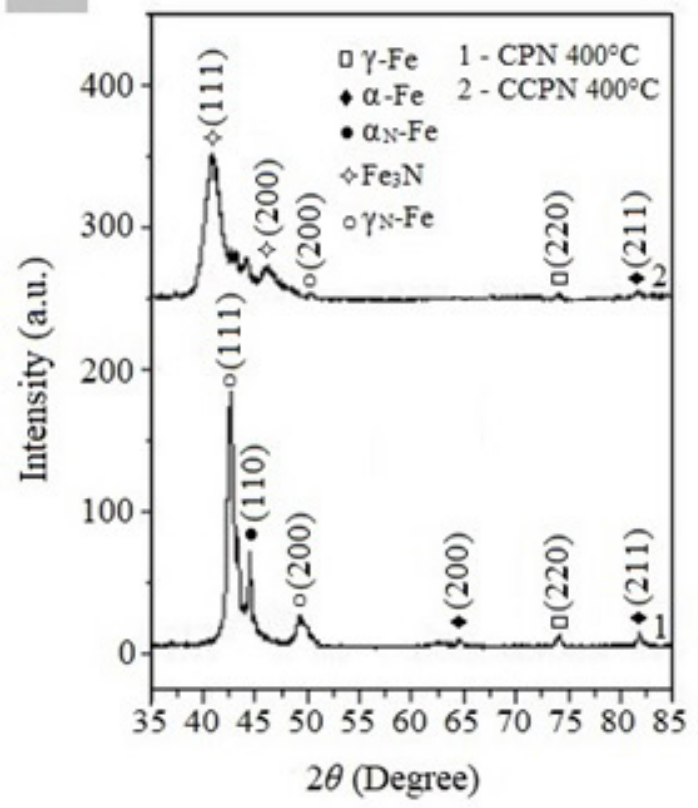

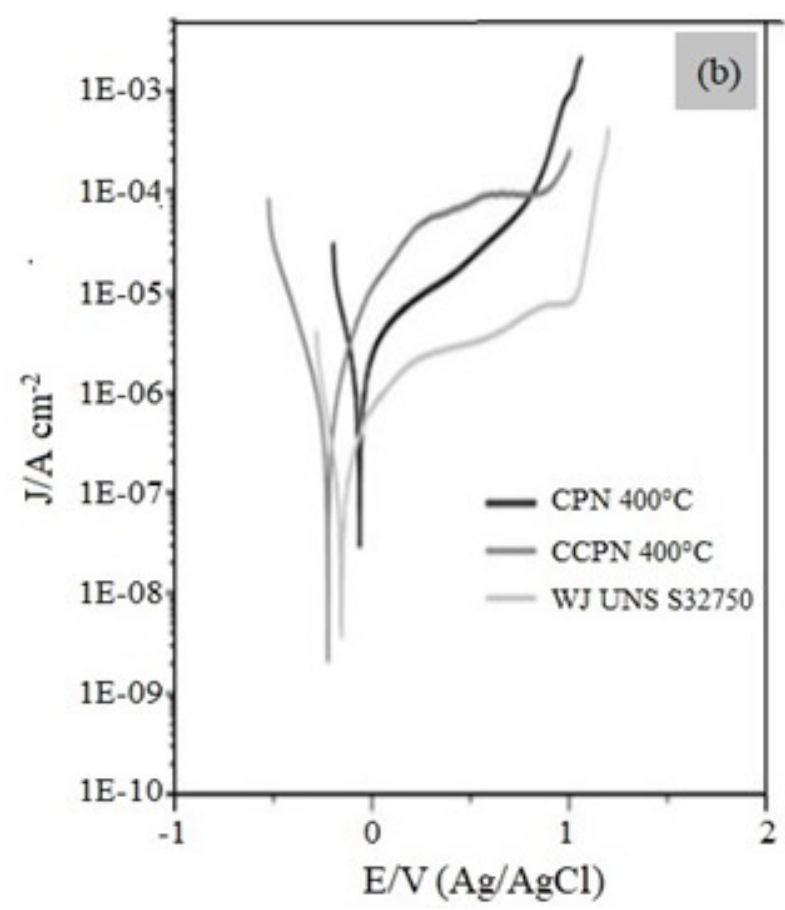

Figure 9. (a) XRD pattern of nitrided samples. (b) Potentiodynamic polarization curves of WJ of UNS S32750 super duplex stainless steel, and conventional plasma nitriding (CPN) and cathodic cage plasma nitriding (CCPN) samples.

Table 5. Average thickness of the nitrited layers, CPN and CCPN.

\begin{tabular}{cccc}
\hline Treatment $/$ Temperature & Compound zone $(\mu \mathrm{m})$ & Diffusion zone $(\boldsymbol{\mu m})$ & $\begin{array}{c}\text { Nitrided layer (compound } \\
\text { zone }+ \text { diffusion zone } \\
(\mu \mathrm{m})) / \text { standard deviation }\end{array}$ \\
\hline $\mathrm{CPN} / 400^{\circ} \mathrm{C}$ & - & 6.22 & $6.22 \pm 0.09$ \\
\hline $\mathrm{CCPN} / 400^{\circ} \mathrm{C}$ & 1.94 & 1.46 & $3.40 \pm 0.07$ \\
\hline
\end{tabular}


Table 6. Corrosion potential values: $\mathrm{E}_{\text {corrosion }}, \mathrm{j}_{\text {corrosion, }}$, and $\mathrm{E}_{\text {pite }}$, extracted from the potentiodynamic polarization curves.

\begin{tabular}{cccc}
\hline Samples & Ecorrosion $(\mathbf{V})$ & jpassivation $\left(\mathrm{A} \cdot \mathrm{cm}^{2}\right)$ & Epite $(\mathrm{V})$ \\
\hline $\mathbf{W J ~ S 3 2 7 5 0}$ & -0.16 & $4.61 \times 10^{-9}$ & 1.03 \\
\hline $\mathbf{C P N} / \mathbf{4 0 0}^{\circ} \mathbf{C}$ & -0.06 & $2.60 \times 10^{-9}$ & 0.83 \\
\hline $\mathbf{C C P N} / \mathbf{4 0 0}^{\circ} \mathbf{C}$ & -0.22 & $2.17 \times 10^{-9}$ & 0.86 \\
\hline
\end{tabular}

$400^{\circ} \mathrm{C}$. The presence of the expanded austenite and expanded ferrite phases detected in the XRD of Figure 9a played a crucial role, as these phases confer excellent tribological properties without considerable losses in corrosion resistance ${ }^{47}$. Additionally, in the literature ${ }^{46}$, samples treated by the CCPN at $400^{\circ} \mathrm{C}$ present higher and more uniform surface hardness when compared to those treated by $\mathrm{CPN}$ at $400^{\circ} \mathrm{C}$; however, it was observed in Figure $9 \mathrm{~b}$ that the results for corrosion were far from expected when compared with the results for the conventionally treated sample. In addition, it can be inferred that the sputtering mechanism of each treatment contributed to this result.

Still in Figure 9a, the presence of $\mathrm{Fe}_{3} \mathrm{~N}$ phase can be seen in the XRD. According to Sousa ${ }^{27}$, the iron nitride has a lower corrosion resistance than the phases obtained in the conventional treatment, besides it has a porous microstructure, facilitating the penetration of chloride ions of the solution in the layer and triggering the pites formation. Gentil ${ }^{48}$ states that pite is the type of localized corrosion processed in points or small areas on the metallic surface producing cavities that present the bottom in an angular shape and depth generally larger than its diameter. In the potentiodynamic polarization curves of Figure 9b, the potential of pite (transpassivation) is observed. It is in the anodic part, in the transition between the ending of the passivation region and the beginning of the abrupt increase of the current density, indicating that there was rupture of the passive film.

Table 6 presents the following values: Corrosion potential $\left(\mathrm{E}_{\text {Corrosion }}\right)$, Corrosion current density $\left(\mathrm{j}_{\text {Corrosion }}\right)$ and Pite potential $\left(\mathrm{E}_{\mathrm{pit}}\right)$. In short, the analysis of corrosion resistance of stainless steels, by means of this electrochemical technique, is not punctual. It uses the values shown in Table 6 , added to the slope of the curve in the passive region, indicating that the greater the angle between this and the $x$-axis (corrosion current density), the more passive the material will be. Considering these assumptions, it is observed that the behavior of welded joints without nitriding is the most resistant against the attack of aggressive chloride ions (Cl-).

\section{Conclusions}

The parameters used in the welding allowed power in the $1.4 \mathrm{~kJ} / \mathrm{m}$ range. This yielded ferrite volumetric fractions of $53.79 \%$ in HAZ and $35.88 \%$ in FZ. These values are in consonance with the literature ${ }^{4}$. Due to the high percentage of austenite in the welded joint, it presented a good resistance to corrosion as can be proven by the potentiodynamic polarization technique. In addition, the curve presented is characteristic of passivation materials; that is, the weld presented films resistant to the chloride ion attacks of the $3.5 \% \mathrm{NaCl}$ solution used.
From the nitrided samples, the one conventionally treated, i.e., by the $\mathrm{CPN}$ technique at $400^{\circ} \mathrm{C}$ showed better results against corrosion when analyzing the result of potentiodynamic polarization $-\mathrm{j}_{\text {passivation }}=2.60 \times 10^{-5} \mathrm{~A} \cdot \mathrm{cm}^{-2}$ and $\mathrm{E}_{\text {pite }}=0.83 \mathrm{~V}$. These were higher due mainly to the presence of the expanded austenite phase detected in XRD. Expanded austenite is a phase that provides high hardness by expanding the $\mathrm{CFC}$ structure of the austenite, resulting from the insertion of the nitrogen into the interstices without significant loss in corrosion resistance. Finally, the CCPN samples exhibited corrosion resistance lower than those conventionally treated mainly by the presence of the $\mathrm{Fe}_{3} \mathrm{~N}(\varepsilon-\mathrm{FeN})$ phase in their nitrided layer. It has low corrosion resistance.

\section{Acknowledgments}

The authors acknowledge the Welding Laboratory from the Mechanical Engineering Course of the Federal University of Uberlândia, Plasma and Electrochemistry Laboratories of the Federal University of Piauí, and to the Federal Institute of Education, Science and Technology of Maranhão for its support during this research.

\section{References}

1. Zhang X, Wang K, Zhou Q, Ding J, Ganguly S, Marzio G, et al. Microstructure and mechanical properties of TOP-TIG-wire and arc additive manufactured super duplex stainless steel (ER2594). Mater Sci Eng A. 2019;762:138097.

2. Tavares SSM, Pardal JM, Lima LD, Bastos IN, Nascimento AM, De Souza JA. Characterization of microstructure, chemical composition, corrosion resistance and toughness of a multipass weld joint of superduplex stainless steel UNS S32750. Mater Charact. 2007;58(7):610-6.

3. Sadeghian M, Shamanian M, Shafyei A. Effect of heat input on microstructure and mechanical properties of dissimilar joints between super duplex stainless steel and high strength low alloy steel. Mater Des. 2014;60:678-84.

4. Cui ZD, Wu SL, Zhu SL, Yang XJ. Study on corrosion properties of pipelines in simulated produced water saturated with supercritical $\mathrm{CO}_{2}$. Appl Surf Sci. 2006;252:2368-74.

5. Silva RCC, Nogueira RP, Bastos IN. Tribocorrosion of UNS S32750 in chloride medium: effect of the load level. Electrochim Acta. 2011;56(24):8839-45.

6. Munoz AI, Julian LC. Influence of electrochemical potential on the tribocorrosion behaviour of high carbon CoCrMo biomedical alloy in simulated body fluids by electrochemical impedance spectroscopy. Electrochim Acta. 2010;55(19):5428-39.

7. Han G, Jiang P, Wang J, Yan F. Effects of $\mathrm{NaCl}$ concentration on wear-corrosion behavior of SAF 2507 super duplex stainless steel. RSC Advances. 2016;6:111261-8.

8. Nilsson JO, Kangas P, Wilson A, Karlsson T. Mechanical properties, microstructural stability and kinetics of $\sigma$-phase formation in $29 \mathrm{Cr}-6 \mathrm{Ni}-2 \mathrm{Mo}-0.38 \mathrm{~N}$ superduplex stainless steel. Metall Mater Trans, A Phys Metall Mater Sci. 2000;31:35-45. 
9. Lippold JC, Kotecki DJ. Welding metallurgy and weldability of stainless steels. Hoboken: John Wiley; 2005.

10. Castro JA, Oliveira EM, Almeida DSS, Fonseca GS, Xavier CR. Effects of local heat input conditions on the thermophysical properties of super duplex stainless steels (SDSS). Mater Res. 2017;20(Suppl 1):153-61.

11. The Norsok Standard. Welding and inspection of piping. Lysaker: Standards Norway; 2004.

12. Fonseca GS, Oliveira PM, Diniz MG, Bubnoff D, Castro JA. Sigma phase in superduplex stainless steel: formation, kinetics and microstructural path. Mater Res. 2017;20(1):249-55.

13. Hsieh RI, Liou HY, Pan YT. Effects of cooling time and alloying elements on the microstructure of the gleeble-simulated heataffected zone of $22 \% \mathrm{Cr}$ duplex stainless steels. J Mater Eng Perform. 2001;10(5):526-36.

14. Paiva JMF, Amorim FL, Soares PC, Veldhuis SC, Mendes LA, Torres RD. Tribological behavior of superduplex stainless steel against PVD hard coatings on cemented carbide. Int J Adv Manuf Technol. 2017;90:1649-58.

15. Nagatsuka K, Nishimoto A, Akamatsu K. Surface hardening of duplex stainless steel by low temperature active screen plasma nitriding. Surf Coat Tech. 2010;205:S295-9.

16. Pinedo CE, Varela LB, Tschiptschin AP. Low-temperature plasma nitriding of AISI F51 duplex stainless steel. Surf Coat Tech. 2013;232:839-43.

17. Kliauga AM, Pohl M. effect of plasma nitriding on wear and pitting corrosion resistance of X2 CrNiMoN 2253 duplex stainless steel. Surf Coat Tech. 1998;98:1205-10.

18. Borges FMR, Leal VS, Guimarães FES, Ferraresi VA, Sousa RRM. Nitretação a plasma da junta soldada do aço inoxidável super duplex SAF 2507. Materia (Rio J). 2019;24(1):e-12305.

19. Pereira JO No, Da Silva RO, Da Silva EH, Moreto JA, Bandeira RM, Manfrinato MD, et al. Wear and corrosion study of plasma nitriding F53 super duplex stainless steel. Mater Res. 2016;19(6):1241-52.

20. Alphonsa J, Padsala BA, Chauhan BJ, Jhala G, Rayjada PA, Chauhan N, et al. Plasma nitriding on welded joints of AISI 304 stainless steel. Surf Coat Tech. 2013;228(S1):S306-11.

21. Araújo AGF, Naeem M, Araújo LNM, Costa THC, Khan KH, Díaz-Guillén JC, et al. Design, manufacturing and plasma nitriding of AISI-M2 steel forming tool and its performance analysis. Journal of Materials Research and Technology. 2020;9(6):14517-27.

22. Naeem M, Raza HA, Shafiq M, Shabbir F, Iqbal J, Díaz-Guillén JC, et al. Improved nitriding capability of nonalloyed steels assisted with active screen plasma treatment. Surf Rev Lett. 2020;27(3):1950118.

23. Silva LC, Libório MS, Lima LLF, Sousa RRM, Costa THC, Naeem M, et al. Deposition of MoS2-TiN multilayer films on 1045 steel to improve common rail injection system. J Mater Eng Perform. 2020;29:6740-7.

24. Yuan YG, Kang JJ, Yue W, Fu ZQ, Zhu LN, She DS, et al. Tribological properties of TC4 titanium alloy treated by plasma nitriding at different temperatures. Journal of Materials Engineering. 2020;48(2):156-62.

25. Forsich C, Heim D, Mueller T. Influence of the deposition temperature on mechanical and tribological properties of a-C:H:Si coatings on nitrided and postoxidized steel deposited by DC-PACVD. Surf Coat Tech. 2008;203(5-7):521-5.

26. Abreu LHP, Naeem M, Borges WFA, Monção RM, Sousa RRM, Abrar M, et al. Synthesis of TiN and TiO2 thin films by cathodic cage plasma deposition: a brief review. Journal of the Brazilian Society of Mechanical Sciences and Engineering. 2020;42(9):496.

27. Sousa RRM. Nitretação em plasma com gaiola catódica: investigação do mecanismo e estudo comparativo com a nitretação em plasma de tensão contínua [tese]. Natal: Universidade Federal do Rio Grande do Norte; 2007.

28. Santos TFA, López EAT, Fonseca EB, Ramirez AJ. Friction stir welding of duplex and superduplex stainless steels and some aspects of microstructural characterization and mechanical performance. Mater Res. 2019;19(1):117-31.

29. Kotecki DJ, Siewert TA. WRC-1992 constitution diagram for stainless steel weld metals: a modification of the WRC-1988 diagram. Weld Res Suppl. 1992;71(5):171-8.

30. Libório MS, Praxedes GB, Lima LLF, Nascimento IG, Sousa RRM, Naeem M, et al. Surface modification of M2 steel by combination of cathodic cage plasma deposition and magnetron sputtered MoS2-TiN multilayer coatings. Surf Coat Tech. 2020;384:125327.

31. Sousa RRM, Araujo FO, Ribeiro KLB, Dumelow T, Costa JAP, Alves C. Ionic nitriding in cathodic cage of AISI 420 martensitic stainless steel. Surf Eng. 2008;24(1):52-6.

32. DeMello JDB, Binder C, Binder R, Klein AN. Effect of nature of nitride phases on microabrasion of plasma nitrided sintered iron. Trib Mater Surf Interf. 2010;4(4):191-6.

33. Bergerhoff G, Brown ID. Inorganic crystal structure database. In: Allen FH, Bergerhoff G, Siever R, editors. Crystallographic databases. Chester, England: International Union of Crystallography; 1987. Chapter 2.2, p. 77-95.

34. Pessoa ARP. Welding on UNS S32750 superduplex austenitic steel plates employed FCAW process [thesis]. Fortaleza: Universidade Federal do Ceará; 2015. [Portuguese].

35. Gunn RN. Duplex stainless steels: microstructure, properties and applications. Cambridge: Woodhead Publishing; 1997.

36. Senatore M, Finzetto L, Perea E. Comparative study between duplex and AISI 304L/316L stainless steels. REM Rev Escola Minas. 2007;60(1):175-81.

37. Modenesi PJ, Marques PV, Santos DB. Introdução a metalurgia da soldagem. Belo Horizonte: DEM; 2006.

38. Videira AM. Influence of heat input of GTAW Welding in phase balance of Ferrite/Austenite of the Duplex UNS S32205 Stainless Steel [dissertation]. Ilha Solteira: Universidade Estadual Paulista "Júlio de Mesquita Filho"; 2016. [Portuguese].

39. Candel EHP. Soldagem dos aços inoxidáveis superduplex UNS S32750 e UNS S32760 [dissertação]. São Paulo: Universidade de São Paulo; 2016.

40. Pinto PSG. Evaluation of the impact resistance of stainless steel joints superduplex welded by pulsed GMAW with different gas mixtures [dissertation]. Porto Alegre: Universidade Federal do Rio Grande do Sul; 2009. [Portuguese].

41. Fonseca CS, Pinheiro IP, Silva SN. Influence of the thermal contribution on the morphology of austenite and the amount of phases in SAF2205 stainless steel duplex plates. Materia (Rio J). 2016;21(1):227-34.

42. Ameyama K, Weatherly GC, Aust KT. A study of grain boundary nucleated widmanstätten precipitates in a two-phase stainless steel. Acta Metall Mater. 1992;40(8):1835-46.

43. Vodárek V, Reip CP, Smetana B, Volodarskaja A. Formation and decomposition of Widmanstätten austenite in GOES belt-casted strips. IOP Conf Series Mater Sci Eng. 2019;668:012016.

44. Ohmori Y, Nakai K, Ohtsubo H, Isshiki Y. Mechanism of Widmanstätten austenite formation in a $\delta / \gamma$ duplex phase stainless steel. ISIJ Int. 1995;35(8):969-75.

45. Christiansen TL, Somers MAJ. Stress and composition of carbon stabilized expanded austenite on stainless steel. Metall Mater Trans, A Phys Metall Mater Sci. 2009;40:1791.

46. Sousa RRM, Araújo FO, Gontijo LC, Costa JAP, Alves C. Cathodic cage plasma nitriding (CCPN) of austenitic stainless steel (AISI 316): influence of the different ratios of the (N2/H2) on the nitrided layers properties. Vacuum. 2012;86(12):2048-53.

47. Reis RF, Maliska AM, Borges PC. Plasma nitriding of an austenitic stainless stell ISO 5832-1: influence of time treatment. Materia (Rio J). 2008;13(2):304-15.

48. Gentil V. Corrosão. Rio de Janeiro: Livros Técnicos e Científicos; 2003. 